\title{
Editorial
}

\section{Brand Managers - a dying breed?}

It's a rum old world. Just when companies are discovering that brands are their most important assets, they decide brand managers are unnecessary. The idea that brands are too important to require management needs qualification: are we playing with language or is this genuinely stupid?

BC (before Camay) brand decisions were made by the top management but there was rarely more than one brand per company. Where that is the case, the role of a specialist brand management team may well be questioned. In a multi-brand company, however, where does the individual brand buck stop? Marketers mostly have themselves to blame, at least according to McKinsey. ${ }^{1}$ They are held guilty of failing to innovate and/or to service the needs of the immediate customer. Maybe the rot set in when innovation was directed to job titles. The central importance of the brand was fudged when 'brand managers' became 'product managers', then 'product group managers', and then 'category controllers'; now they are 'consumer integrators'.

The pursuit of fashion at the expense of fundamentals was ever a marketing temptation; it is hard to be brand loyal when customers and the sales director have a gun labelled 'category management' pointed at one's head.

Professor Thomas set us a few questions in his editorial, 'Whither Brand Management?' last autumn. Underlying my answers would be a consideration of the brand manager's role as an asset maximiser. If a brand, or 'brand equity', is such an important asset, and it is, then management should farm it. A farmer, you will remember, should live as if he will die tomorrow but farm as if he will live forever. Brand managers too should be in all the fashionable hotspots and have a doit-now philosophy. At the same time, they should manage the brand as though they will be managing it for the rest of their lives, not skipping off after a few price promotions. Whether they are part of a team, in the modern fashion, or the mini-general managers of old, profits will take care of themselves, in time, provided brand equity is increased. Managing for short term profits, however, may well strip the asset of its profit-bearing capacity.

These paragraphs were not to point out that the first ' $h$ ' in whither is silent, nor that brand managers will find themselves out of work unless they stop chasing shadows and innovate real value into their brands. They were to clear the throat to draw your attention to the centrality of brands to business of all kinds. Even banks. UK High Street banks have had 'marketing' for years. Rather, they ran advertising and promotions but marketing specialists (oxymoron?) were kept well away from the mainstream business. NatWest - full marks - are now changing that. Will their CEO's title change to 'brand manager'? Perhaps not yet.

This splendid issue of the Journal illustrates these themes and recognises the centrality of the brand and brand management from whichever direction one looks. A 'brand' is always an asset in some sense but shows up in many forms.

Grahame Dowling considers various aspects of corporate reputation. A firm of 
lawyers may not see its public face as an asset that can be counted and yet that is the essence of the goodwill that incoming partners, in some way, buy into. Recognising the importance of the desired reputation is the first step to managing it deliberately.

Philip Lawder and Simon Sholl likewise acknowledge the brand as an asset on their way to that most fundamental of all marketing insights: understanding the consumer's view. Consumers rarely tell us what is really in their minds, even when they know what is in their minds, and mostly they don't. Habits enable us to reach out for brands without having to make choices. Thinking is hard work and takes valuable time. Perhaps the English and American educational systems, in their dedication to removing any need for pupils to think at all, are coincidentally providing the perfect environment for branding relative to, say, Germany.

Which takes us to 'The View from the Couch' in which Mike Bloxham considers television sponsorship. This is still a new form of brand exposure in the UK. The paper is especially important for marketers choosing between TV advertising and/or sponsorship.

These days, marketers tread warily in marketing to children. Some inadequately supported charges have recently been addressed to food marketers, for instance, and stoutly resisted by the Advertising Association. Research into the effectiveness of the Esso Tiger Tails campaign many years after it finished indicated that it influenced buying behaviour by those far too young to have been buying petrol when it ran. Sam Blass takes us into the use of visual images in adding value to children's products from a practitioner's viewpoint. Any brand, perhaps, becomes one of a whole collection of personalitites, real and mythical, from entertainment and the supermarket, which inhabit the world of young people.

When one sees the brand as one person in a network of personal relationships, it be- comes clear why one cannot measure brand equity in money terms. What is a friendship worth to the nearest thousand pounds? One associates with brands whose personalities mesh well with one's own. The men buying Armani suits are not the same as those buying the Daks brand, shh, 'Portly'. Once we recognise that brands are assets immeasurable in financial terms, it is a short step to reviewing what measures are most suitable. We need measures of some sort to manage brands at all.

David Aaker's ${ }^{2}$ classic on Brand Equity included the absence of a clear brand equity custodian as an indicator of a company's under-emphasis on brand building. If something is left to everyone, it is left to no one. It is wonderful to involve the whole company in brand building, ie marketing, so long as there is a single point of reference that ensures their activities are additive, not in conflict. The marketing mix is, in principle, synergistic: promotions work better with simultaneous advertising, and vice versa, but that depends on a clear positioning consistently applied.

The Jeremiahs are wrong. Brands are not finished and nor are brand managers. Before returning to business as usual, however, we should ask what caused the confusion, if not hostility, in the first place. Distance from the marketplace, lack of real innovation, pursuit of fashion and superficiality have all contributed to a sense that marketers have taken, or have been inflicted with, power without responsibility. Separated from the mainstream of the business, many brand managers have been accountable for spending the marketing budget but not the bottom line, still less brand equity.

Thankfully that is changing. Brands are being managed by cross-functional teams with the brand manager, with whatever title, as coordinator. Brand equity is beginning to be measured alongside profitability.

We hope that you will enjoy this issue. Please write to tell us, or to express other 
views. Professor Thomas still needs his questions answered, but 'Whither Brand Management?' should be onward and upward.

\section{References}

(1) Brady, John and Davis, Ian (1993) 'Marketing's mid-life crisis', The McKinsey Quarterly, Number 2 and George, Michael, Freeling, Anthonu and Court, David (1994) 'Reinventing the Marketing Organisation', The McKinsey Quarterly, Number 4.

(2) Aaker, David (1991) 'Managing Brand Equity', The Free Press, New York. 